McGill Law Journal

Revue de droit de McGill

\title{
Kenneth M. Smookler, Farr \& Beyond: Lawyers for the Otherworldly (Toronto: Wall \& Emerson, 2016), p 118, ISBN 978-1-895131-26-0
}

\section{Simon Stern}

Volume 62, numéro 4, june 2017

URI : https://id.erudit.org/iderudit/1043166ar

DOI : https://doi.org/10.7202/1043166ar

Aller au sommaire du numéro

Éditeur(s)

McGill Law Journal / Revue de droit de McGill

ISSN

0024-9041 (imprimé)

1920-6356 (numérique)

Découvrir la revue

Citer ce compte rendu

Stern, S. (2017). Compte rendu de [Kenneth M. Smookler, Farr \& Beyond: Lawyers for the Otherworldly (Toronto: Wall \& Emerson, 2016), p 118, ISBN 978-1-895131-26-0]. McGill Law Journal / Revue de droit de McGill, 62(4), 1281-1284. https://doi.org/10.7202/1043166ar d'utilisation que vous pouvez consulter en ligne.

https://apropos.erudit.org/fr/usagers/politique-dutilisation/ 
McGill Law Journal - Revue de droit de McGill

\section{Book NoTE-}

Kenneth M. Smookler, Farr \& Beyond: Lawyers for the Otherworldly (Toronto: Wall \& Emerson, 2016), p 118, ISBN 978-1-895131-26-0.

The shelf of books devoted to legal humour is a capacious one, and the titles range across a variety of forms. Theobald Mathew's Forensic Fables ${ }^{1}$ and A.P. Herbert's Misleading Cases ${ }^{2}$ satirize the habits of lawyers and judges by offering up imaginary cases, and this has tended to be the preferred approach, sometimes focusing on the forensic activities surrounding these disputes (as with Mathew's fables) and sometimes producing the judgements themselves (as in Herbert's bemused jurisprudence). The latter genre also includes Alexander Pope's celebrated decision in Stradling $v$. Stiles, ${ }^{3}$ the case of the "black and white [h]orses"4 taken from Scriblerus's Reports. Another common tactic is to see what lies in the existing legal record. John B. McClay and Wendy L. Matthews' Corpus Juris Humorous $^{5}$ is based entirely on actual cases, while R.E. Megarry, in his three

1 See O (pseudonym of Theobald Mathew), Forensic Fables, complete ed (London: Butterworths, 1961) (collecting the contents of four volumes by the same author: Forensic Fables (London: Butterworth, 1926); Further Forensic Fables (London: Butterworth, 1928); Final Forensic Fables (London: Butterworth, 1929); Final Forensic Fables: Second Series (London: Butterworth, 1932)).

2 See AP Herbert, Misleading Cases in the Common Law (London: Methuen, 1927); AP Herbert, More Misleading Cases (London: Methuen, 1930); AP Herbert, Still More Misleading Cases (London: Methuen, 1933); AP Herbet, Uncommon Law: Being Sixty-Six Misleading Cases Revised and Collected in One Volume, Including Ten Cases Not Published Before (London: Methuen, 1935).

3 See Alexander Pope, "A Specimen of Scriblerus's Reports: Stradling versus Stiles" in The Works of Alexander Pope Esq (London: Bathurst, 1770) vol 6, 279. See also Alexander Pope, "Stradling versus Stiles" in Rosemary Cowler, ed, The Prose Works of Alexander Pope: The Major Works, 1725-1744, vol 2 (Hamden, Conn: Archon Books, 1986) 129 at 131; Francis Lieber, Legal and Political Hermeneutics, 3rd ed (St Louis: FH Thomas, 1880) at 76, 331-32; $R$ v Davis (1851), 5 Cox CC 237, Campbell CJ (citing the "great case of Stradley v Styles" at 238).

4 Dr Arbuthnot \& Mr Pope, "Memoirs of the Extraordinary Life, Works, and Discoveries of Martinus Scriblerus" in The Works of Alexander Pope, Esq, vol 3, Part 2 (London: Dodsley, 1742) at 122 .

5 See John B McClay \& Wendy L Matthews, Corpus Juris Humorous: A Compilation of Humorous, Extraordinary, Outrageous, Unusual, Colorful, Infamous, Clever and Witty Reported Judicial Opinions and Related Materials Dating from 1256 A.D. to the Present (Santa Ana, Cal: MAC-MAT, 1991). 
volumes of legal miscellanea, collects cases, doctrine, and lore. ${ }^{6}$ Somewhere in between are the imaginary dialogues of litigants in real cases, as in Sir George Hayes' argument for pleading reform, embellished from the materials in Crogate's Case. ${ }^{7}$ Indeed, arguments for procedural reform have spawned a whole subgenre of legal poetry, including most notably John Anstey's poem The Pleader's Guide, ${ }^{8}$ which went through eight editions in thirty years.

Kenneth Smookler's Farr \& Beyond ${ }^{9}$ is a welcome addition to this shelf. Smookler's novel approach is to generate pleadings, memos, and letters concerning the protagonists of various fairy tales, fables, and literary classics. His turn to the world of fantasy (including myth and science fiction) is, in some ways, a logical extension of the satirical strain in earlier contributions to the field, while his resort to the bureaucratic forms that ground the lawyer's art serves at once to highlight the absurdity of the enterprise and to lend these efforts an eerie air of familiarity. If the file and the memo are the paradigmatic tools that lawyers use to tame uncertainty and to promote their own species of rationality, ${ }^{10}$ Smookler's use of these forms shows how they can be pressed into service for nearly any end, how templates take on a life of their own that can make the most outlandish proposition seem plausible. While there has been a significant

6 See RE Megarry, Miscellany-at-Law: A Diversion for Lawyers and Others (London: Stevens \& Sons, 1955); Hon Sir Robert Megarry, A Second Miscellany-at-Law: A Further Diversion for Lawyers and Others (London: Stevens \& Sons, 1973); Rt Hon Sir Robert Megarry, A New Miscellany-at-Law: Yet Another Diversion for Lawyers and Others, ed by Bryan A Garner (Oxford: Hart, 2005).

7 See Crogate's Case (1608), 8 Co Rep 66b, 77 ER 574; Sir George Hayes, Crogate's Case: A Dialogue in ye Shades, on Special Pleading Reform (London: BE Bult, 1854). See also WS Holdsworth, A History of English Law (London: Methuen, 1944) vol 9 at 417-31; WS Holdsworth, "The New Rules of Pleading of the Hilary Term, 1834" (1923) 1:3 Cambridge LJ 261 at 271-73; Rt Hon Sir Frederick Pollock, The Genius of the Common Law (New York: Columbia University Press, 1912) at 27-29; Warren Swain, The Law of Contract, 1670-1870 (Cambridge: Cambridge University Press, 2015) at 175, n 25.

8 See John Surrebutter (pseudonym of John Anstey), The Pleader's Guide, a Didactic Poem, in Two Books, Containing the Conduct of a Suit at Law, with the Arguments of Counsellor Bother'um, and Counsellor Bore'um in an Action Betwixt John-a-Gull, and John-a-Gudgeon, for Assault and Battery, at a Late Contested Election (London: Cadell, 1796). See also The Locusts: Or, Chancery Painted to the Life, and the Laws of England Try'd in Forma Pauperis. A Poem (London: Nutt, 1704); Rev James Holme, The Castle of Despair; or, A Vision of Chancery: An Allegorical Poem, in Three Cantos (London: Thomas, 1824); Reginald James Blewitt, The Court of Chancery: A Satirical Poem (London: Kay, 1827).

9 See Kenneth M Smookler, Farr \& Beyond: Lawyers for the Otherworldly (Toronto: Wall \& Emerson, 2016).

10 See generally Cornelia Vismann, Files: Law and Media Technology, translated by Geoffrey Winthrop-Young (Stanford: Stanford University Press, 2008); John Guillory, "The Memo and Modernity" (2004) 31:1 Critical Inquiry 108. 
amount of writing on the gothic and the law, its emphasis has been on the law's uncanny powers, ${ }^{11}$ whereas in Smookler's hands, the fantastic almost always results in farce. ${ }^{12}$ The Pied Piper proposes to recover against the Town of Hamelin for a variety of claims ranging from breach of contract and defamation to inflection of mental distress. ${ }^{13}$ Cinderella, harassed by allegations of operating an unlicensed pumpkin, cruelty to mice, and breach of contract for domestic services, receives a reassuring analysis from her counsel, showing why all the claims are meritless-the result of either overzealous enforcement or spiteful motives that have no jurisprudential support. ${ }^{14}$ Captain Hook, rendered incapable of pursuing his lawful calling through loss of his hand, and now suffering from a host of fears and complexes relating to clocks and crocodiles, demands both general and special damages from Peter Pan, in hopes of being made whole..$^{15}$ Ali Baba, having escaped criminal liability after the discovery of forty corpses in his cave, considers raising some property-related charges against the officious neighbour who alerted the authorities, but is advised by counsel that it is always best to avoid litigation, and that he can catch more flies with honey than vinegar. ${ }^{16}$

In each case, Smookler mixes together a blend of doctrinal creativity, strategic advocacy, and bemusement at the foibles of lawyers. The citizens of Hamelin, doubtless considering themselves the aggrieved parties, are forced to confront the extent of foreseeable harm flowing from their accusations about the piper. Captain Hook's complex maneuverings, involving the defence of necessity and the illegality of dueling, shift the onus to Peter Pan to justify what he had presumably regarded as an airtight case.

11 See e.g. David Punter, Gothic Pathologies: The Text, the Body and the Law (Basingstoke, UK: Macmillan Press, 1998); Sue Chaplin, The Gothic and the Rule of Law, 1764-1820 (Basingstoke, UK: Palgrave Macmillan, 2007); Bridget M Marshall, The Transatlantic Gothic Novel and the Law, 1790-1860 (Farnham, UK: Ashgate, 2011); Anne McGillivray, "He Would Have Made a Wonderful Solicitor': Law, Modernity and Professionalism in Bram Stoker's Dracula" in W Wesley Pue \& David Sugarman, eds, Lawyers and Vampires: Cultural Histories of Legal Professions (Oxford: Hart, 2003) 225.

More usually, writers turn to fairy tales and other kinds of fantasy as a means of engaging in legal storytelling (see e.g. George M Eubanks, "Peaceful Picketing: A Fairytale in Three Parts", Comment (1959) 8 J Public L 308; Dale Gibson, "Not-So-White, the Ten Dwarfs, and the Nine Wise Ones: A Constitutional Fairy-Tale" (1989) 18:1 Man LJ 1; Daniel A Farber, “Terminator 21/2': The Constitution in an Alternate World" (1992) 9:1 Const Commentary 59). On the genre more generally, see David Gurnham, "The ForestPath of Law and the Wolf-Belly of Justice: Legal Theory and Fairy Tale" (2005) 56:4 N Ir Leg Q 585). See Smookler, supra note 9 at 3-6.

See ibid at $45-49$.

See $i b i d$ at $51-54$.

16 See ibid at $67-71$. 
Always open to new theories that would monetize their clients' injuries, or that would serve as opportunities to drum up custom from others who are similarly afflicted, Smookler's lawyers are ever on the alert for any colourable argument that might offer cover. At the same time, they delight in trumpeting their deep commitment to legal ethics and dwelling on the untold hours of research that may not be adequately reflected in a short memo. They seem happiest when contemplating the various ways in which they might translate a client's victory into an ongoing stream of profits, either by sharing in a percentage of the client's income or by capitalizing on a client's social status, as a means of acquiring more business. Eager to claim the expertise and flexibility of a full-service law firm, offering an extensive menu of options that take their clients far beyond litigation as the default solution, these lawyers are happy to accept unconventional cases and to propose unconventional answers. The result is a jurisprudence that bears comparison with the world of Mathew and Herberta world of exuberant lawyering in which the bombastic and the hapless are rarely far apart.

Simon Stern 